DOI: https://doi.org/10.11144/Javeriana.umed61-4.ulce

\title{
Factors Associated with the Prevalence of Pressure Ulcers in a University Hospital in Bogotá, Colombia
}

\section{Factores asociados a prevalencia de úlceras por presión en un hospital universitario en Bogotá (Colombia)}

David Andrade Fonseca National Research Coordinator B. Braun Avitum, Colombia

Sandra J. Hernández Ordóñez

Coordinator of the Neuroscience Service of the Hospital Universitario San Ignacio, Bogotá, Colombia

María Elizabeth Gómez

Professor at Faculty of Nursing, Pontificia Universidad Javeriana, Bogotá, Colombia

Julie Johana Rojas Villamil

Head Nurse of Cardiovascular Surgery, Hospital

Universitario San Ignacio, Bogotá, Colombia

Nydia Esmeralda Ayala

Nurse, Colombia

Yurani Andrea Alfonso

Emergency Coordinator at Clínica Nogales, Bogotá,

Colombia

Eliana Katherine Céspedes G.

Quality audit nurse at Hospital Universitario San

Ignacio, Bogotá, Colombia

Francy Helena Flórez Amaya

Access Executive in Farma de Colombia, Colombia

Gina Alexandra Daza

Hospital Management Nurse at Hospital Universitario

San Ignacio, Bogotá, Colombia
Francisco Javier Sabogal Nurse manager of the emergency unit of the Hospital Universitario San Ignacio, Bogotá, Colombia

JoHAn Andrés Rodríguez

Marrow Transplant Nurse, Hospital Universitario San Ignacio, Bogotá, Colombia

Víctor Alfonso López S. Nurse Auditor at Heon Health On Line, Colombia

Claudia Patricia Rubio Head Nurse in Endocrinology, Hospital Universitario San Ignacio, Bogotá, Colombia

Liliana Marcela Cuspoca Director of Nursing Service, Hospital Universitario San Ignacio, Bogotá, Colombia

${ }^{a}$ Corresponding author: m.gomezn@javeriana.edu.co

How to cite: Andrade Fonseca D, Hernández Ordóñez SJ, Gómez ME, Rojas Villamil JJ, Ayala NE, Alfonso YA, Céspedes EK, Flórez Amaya FH, Daza GA, Sabogal FJ, Rodríguez JA, López VA, Rubio CP, Cuspoca LM. Factors associated with the prevalence of pressure ulcers in a university hospital in Bogotá, Colombia. Univ. Med. 2020;61(4). https://doi.org/10.11144/Javeriana.umed61-4.ulce 


\begin{abstract}
Introduction: Pressure ulcers are skin lesions that occur as a result of an ischemia process; this type of lesions is considered very important in the health context. Objective: To identify associated factors with the appearance of pressure ulcers in hospitalized patients over 16 years old, in a teaching hospital in Bogotá Colombia during 2013. Materials and methods: A casecontrol study was carried out, based on a secondary information source. Some variables and their relationship with the presentation of pressure ulcers in each case were analyzed. Results: 228 patients were included, 114 cases, 114 controls, the bivariate analysis to identify the factors associated with the risk of presenting pressure ulcers: age equal to or greater than 45 years, pathologies of respiratory etiology, with levels of hemoglobin and albumin below the range expected for sex and age, multivariate analysis that patients older than 45 years, hemoglobin below the expected level by sex and age, have a high risk of presenting pressure ulcers for each day of hospital stay. Conclusions: The early identification of factors associated with pressure ulcers constitutes a fundamental pillar of care.

Keywords

nursing care; pressure ulcer; risk factors.
\end{abstract}

\section{RESUMEN}

Introducción: Las úlceras por presión son lesiones de la piel resultado de un proceso de isquemia y son un importante problema en el contexto de la salud. Objetivo: Identificar los factores asociados con la aparición de úlceras por presión en pacientes hospitalizados mayores de 16 años de edad, en el Hospital Universitario San Ignacio (Colombia) durante 2013. Materiales y métodos: Se realizó un estudio de casos y controles, a partir de una fuente de información secundaria. Se analizaron algunas variables y su relación con la presentación de úlceras por presión en cada caso. Resultados: Se incluyeron 228 pacientes, 114 casos, 114 controles. El análisis bivariado permitió identificar factores asociados al riesgo de presentar úlceras por presión: edad igual o mayor de 45 años, patologías de etiología respiratoria, con niveles de hemoglobina y albúmina por debajo del rango esperado para sexo y edad. El análisis multivariable determinó que los pacientes mayores de 45 años, con hemoglobina por debajo del nivel esperado por sexo y edad, tienen un alto riesgo de presentar úlceras por presión por cada día de estancia hospitalaria. Conclusiones:La identificación temprana de factores asociados a úlceras por presión constituye un pilar fundamental en el cuidado.

Palabras clave

úlceras por presión; factores asociados; cuidados de enfermería.

\section{Introduction}

Pressure ulcers (PUs) are skin lesions that originate after a process of ischemia that can necrotize areas of the epidermis, dermis, subcutaneous tissue or muscle where they settle, even affecting the joint and bone. Generally, these lesions are the result of the compression of soft tissue between a bony prominence and an external surface for a prolonged period of time $(1,2)$.

The factors associated with the presentation of PU have been a topic of interest for different health disciplines, since they involve economic and social effects with implications for patients and their families or caregivers, related to the extension of hospital stay times, which translates into an increased burden of morbidity and mortality, increased health costs, as well as long and painful rehabilitation processes (3-5).

Globally, the rate of PU in hospitals is diverse: it varies between $5.1 \%$ and $28.3 \%$, as follows: Japan with $5.1 \%$, Spain with $8 \%$, Italy with $8,3 \%$, the United States with 15\%, the Netherlands with 23.1\% and Canada with 26\% (6).

Knowing the dimension of a health problem, such as PU, allows professionals to implement actions aimed at preventing and controlling them. In Peru, in 2017, Chacón-Mejía and Del Carpio-Alosilla (7) conducted a retrospective analytical observational study to determine clinical indicators associated with PU. They found that older adults with hypoalbuminemia, anemia or lymphopenia are at high risk. Barrera Arenas et al. (8), in 2016, conducted a crosssectional study with the aim of identifying the prevalence of $\mathrm{PU}$ in hospitalized patients in Mexico City and found high prevalence in heels, sacrum and buttocks. In Colombia, according to data from the Ministry of Health (6.9), documented by a study from the Universidad Nacional de Colombia, they report that PU appears in $3 \%$ to $10 \%$ of hospitalized patients, that the incidence rate ranges from $7.7 \%$ to $26.9 \%$, being more frequent in the population over 70 years of age.

The Norton Scale was designed by Doreen Norton in 1962 and allows the risk category of 
PU to be estimated. This requires five categories to be met: physical condition, mental state, activity, mobility and incontinence. The scores obtained allow the person to be classified in a risk category: very high, high, medium or minimum risk. Any person who scores less than 14 points is considered at risk.

When PUs were classified as a preventable events affecting the quality of care (3), during 2012 at Hospital Universitario San Ignacio (HUSI), the Norton Scale was implemented to identify the risk category of PU in hospitalized patients. Once the adherence to the application of this scale was measured, the present study was pertinent to characterize the specific population that presented PUs greater than grade II that was hospitalized during 2013, in order to formulate improvement plans in the guidelines and protocols related to patient care in relation to this risk.

\section{Materials and methods}

Based on the 2013 PU database, consolidated by the HUSI Nursing Service, it was decided to carry out an analytical observational case-control study. Thus, the following selection criteria were established.

\section{Inclusion criteria:}

Patients over 16 years of age (who are considered an adult population within the hospital care protocol).

Patients with a hospital stay of more than 7 days.

\section{Exclusion criteria:}

Records of patients who arrived at the institution with the presence of some type of PU.

Definition of cases. Patients who met the selection criteria for PU developed within the institution, identified through the report in the
PU format of the HUSI Quality Assurance Office and confirmed by the ulcer clinic nursing staff.

Definition of controls. Patients who met the selection criteria who did not develop PU during their hospital stay; but who at the time of applying the risk assessment scale would have been at high risk of developing PU, according to the Norton Scale score.

Sample size. It was calculated through the statistical program Epidat version 4.0, for a 1:1 ratio (case/control). Nutritional status was taken into account with an OR of 2.2 (10), as a variable associated with an exposure probability in the case group of $59 \%$ and in the control group of $35 \%$. A sample size of 228 patients was calculated to obtain a statistical power of $80 \%$ and thus detect a difference with a 95\% confidence level.

Collection of information. The study population was searched in the SAHI electronic medical record of the HUSI. An instrument was designed, piloted and approved by a group of PU expert nurses. This instrument was manually filled in and classified each patient as a case or control, depending on the outcome during the hospital stay. From this, an additional database (secondary source) was created in Excel 2013 format.

Analysis of the information. The Stata version 12 tool was used. Central tendency and dispersion measures were calculated for the quantitative variables, and frequency and percentage distribution tables were calculated for the qualitative variables. With a univariate analysis, associations of the selected risk variables with the incidence of ulcer were identified, and then a multivariate analysis was performed with those variables that showed significant association. A logistic regression model using the backward method was used, with OR calculation and $95 \%$ confidence level. Finally, a model was obtained that exposes factors associated with the increase of PU in adult patients hospitalized at HUSI.

\section{Results}

228 patients were included, of which 114 presented PU during their hospital stay (cases); 
while 114 did not (controls). In the case group, the average stay was shorter, 17 days (SD: 13), compared to the control group, which reported an average stay of 29 days (SD: 21). In both groups there was a predominance of age over 63 years.

The univariate analysis allowed identifying the following factors associated with the risk of developing PU: patients aged 45 years or older, diagnosed with pathologies of respiratory etiology, stuporous, therefore bedridden (poorly functional), with bladder catheter, with amounts of hemoglobin and albumin below the expected range for sex and age, being managed with inotropic drugs, anxiolytics, antipsychotics and antidepressants. The multivariate analysis determined that patients over 45 years old, with hemoglobin below the expected range for sex and age, are at high risk of developing $\mathrm{PU}$ for each day of hospital stay (Table 1).

\section{Table 1.}

Distribution of the variables identified in the univariate analysis associated with the risk of pressure ulcers in adults hospitalized at HUSI during 2013

\begin{tabular}{|c|c|c|c|c|c|c|}
\hline Variable & $\begin{array}{c}\text { Controles } \\
(\mathrm{n}=114)\end{array}$ & $\%$ & $\begin{array}{c}\text { Casos } \\
(\mathrm{n}=114)\end{array}$ & $\%$ & OR & IC $95 \%$ \\
\hline \multicolumn{7}{|l|}{ Edad } \\
\hline $45-62$ & 20 & 17,54 & 34 & 29,82 & 5,1 & $(2.002 ; 12.990)$ \\
\hline 63 o más & 67 & 58,77 & 71 & 62,28 & 3,179 & $(1.393 ; 7.254)$ \\
\hline \multicolumn{7}{|l|}{ Diagnosticos } \\
\hline Respiratorio & 15 & 13,15 & 34 & 29,82 & 2,805 & $(1.427 ; 5.510)$ \\
\hline \multicolumn{7}{|l|}{ Albumina } \\
\hline Baja & 37 & 86,05 & 76 & 97,44 & 6,162 & $(1.186 ; 32.017)$ \\
\hline \multicolumn{7}{|l|}{ Hemoglobina } \\
\hline Baja & 65 & 57,52 & 91 & 81,25 & 3,338 & $(1.622 ; 6.870)$ \\
\hline \multicolumn{7}{|l|}{ Movilidad } \\
\hline Encamado & 41 & 35,96 & 79 & 71,17 & 8,67 & $(2.753 ; 27.308)$ \\
\hline \multicolumn{7}{|l|}{ Sondas } \\
\hline Sonda Vesical & 61 & 53,51 & 81 & 71,68 & 2,199 & $(1.268 ; 3.813)$ \\
\hline \multicolumn{7}{|c|}{ Estado de conciencia } \\
\hline Estuporoso & 8 & 7,02 & 32 & 28,32 & 6,462 & $(2.767 ; 15.094)$ \\
\hline \multicolumn{7}{|l|}{ Medicamentos } \\
\hline Inotropicos & 9 & 7,89 & 26 & 22,81 & 3,447 & $(1.535 ; 7.742)$ \\
\hline A.A.A & 21 & 18,42 & 36 & 31,58 & 2,044 & $(1.103 ; 3.787)$ \\
\hline \multicolumn{7}{|l|}{ Servicio } \\
\hline UCl & 12 & 10,53 & 52 & 46,02 & 10,833 & $(1.103 ; 3.787)$ \\
\hline \multicolumn{7}{|c|}{ Estancia hospitalaria } \\
\hline Promedio (DE) & 16,807 & 13,18 & 29,168 & 20,66 & 1,049 & $(1.028 ; 1.070)$ \\
\hline
\end{tabular}

The multivariate analysis estimates that patients older than 45 years of age, with haemoglobin below $8 \mathrm{~g} / \mathrm{dl}$, for each day of hospital stay, are at risk of developing PU (Table 2).

\section{Table 2}

Multivariate analysis of factors associated with the increased prevalence of pressure ulcers in adult patients hospitalized at HUSI in 2013

\begin{tabular}{|l|c|c|}
\hline & OR & IC $95 \%$ \\
\hline CI-MI-Varias & 2,6 & $(0,39 ; 17,91)$ \\
\hline Cirug-Neuroc & 0,82 & $(0,13 ; 5,63)$ \\
\hline Urgencias & 1 & \\
UCI & 1,35 & $(0,2 ; 9,04)$ \\
\hline Noveno Piso & 8,51 & $(1,24 ; 58,37)$ \\
\hline Hemoglobina & & \\
Baja & 2,52 & $(1,07 ; 5,93)$ \\
Alta & 1,01 & $(0,29 ; 3,55)$ \\
\hline Edad & & \\
\hline $16-44$ & & \\
\hline $45-62$ & 8,56 & $(2,51 ; 29,14)$ \\
\hline 63 o más & 4,99 & $(1,67 ; 14,86)$ \\
\hline Esrtancia Hospitalaria & & \\
Estancia (dias) & 1,05 & $(1,02 ; 1,07)$ \\
\hline
\end{tabular}

\section{Discussion}

In the healthcare and institutional field, it is common to measure certain indicators that directly or indirectly speak of the quality of health care, of which some topics are more sensitive for nurses, such as the development of PU during the hospital stay of a few patients $(11,12)$. The associated factors for the development of PU have been a topic of interest for different health areas, because they imply economic effects with social and emotional implications for patients and their families, given the lengthening of hospital stay, the increase in health costs and morbimortality, the appearance of painful healing processes, the alteration of self-esteem and the unfortunate outcomes, such as sepsis and death $(1,4,8,13)$.

Control of the incidence of PU has become one of the pillars of nursing care; therefore, it is important to formulate strategies that result in its prevention (14). The prevalence of PU in the hospitalized population is approximately $29 \%$. It predominates in patients with prolonged hospitalization that remain in bed, the vast majority of whom are subject to deficits in consciousness resulting from a pathological or 
induced process, as occurs in intensive care units $(13,15)$.

Studies conducted in South America have reported incidence rates of $\mathrm{PU}$ ranging from $25.8 \%$ to $62.5 \%$. Male sex, age and body mass index stand out as factors strongly associated with the risk of skin lesions $(13,16)$. The patient's age has been shown to be a factor strongly related to the risk of developing PU because the body undergoes age-related transformations, such as decreased muscle mass, loss of skin elasticity, reduced frequency of cell renewal, as well as decreased texture and thickness. These impending changes of a physiological process predispose, along with factors such as humidity, friction and pressure, to the imminent risk of skin injuries. Our study coincides with establishing the age over 45 as a statistically and clinically significant risk factor for presenting PU; hence the importance of intensifying actions aimed at preventing them in this age group $(17,18)$.

The nutritional status contributes to the body's organic defense, because it maintains the integrity of the outermost surface of our body, the skin. When this is affected, the nutritional state of the patient favors the renewal, and healing, among other processes of tissue regeneration. When due to health conditions the patient must remain with a part of his body or the whole body exposed to risk factors such as pressure, friction or humidity, the mobilization, massage and lubrication of the skin allow the circulation to be restored. Low concentrations of hemoglobin and albumin in the blood have been shown to be significantly associated with the risk of PU; hence the importance of knowing serum levels in advance, in order to aim care towards preventive activities that mitigate the risk by combating possible causative factors.

The most prevalent diseases reported in the literature refer to the cardiovascular, musculoskeletal and digestive systems (19-21). Although the results in our study showed that these systems are not significantly associated with the risk of PU in adults hospitalized at HUSI, statistical significance was evidenced in patients with low hemoglobin concentrations, which in turn decreases tissue oxygenation. This association allows us to establish an important question for further studies: do patients with respiratory pathology with low hemoglobin have a higher risk of presenting PU than patients with respiratory pathology with adequate amounts of hemoglobin in their blood?

Prolonged bed rest reduces the blood flow to certain areas of the body, and consequently of the skin, which is under pressure. Having a decrease in oxygenated blood flow due to respiratory pathology and, therefore, low hemoglobin concentration in the blood potentially increases the risk of presenting skin injury. Nursing activities should focus on promoting circulation in areas under pressure, promoting blood flow, ensuring good ventilation and good oxygen concentration in the blood. Nursing care focuses on identifying the cause leading to the consequence. This will ensure the prevention of unfavourable events in the subject that requires care (15).

Lower than normal haemoglobin was identified as associated with the occurrence of PU (OR: 2.52; 95\% CI: 1.07-5.93). The literature warns that anemia is one of the intrinsic factors of the patient for the appearance of PU, as well as low levels of serum albumin, considered a marker of malnutrition (11). However, in the present study there were limitations in obtaining albumin values in the entire population, due to lack of data in the clinical history.

The present study made it possible to establish the baseline for making adjustments to the institutional instructional package of $\mathrm{PU}$, a guide document for prevention and management. The early identification of factors associated with ulcer development is a fundamental pillar in the formulation and implementation of nursing care plans.

In relation to length of stay, some studies have reported an average of 11 days $(22,23)$, which is considerably lower than the average found in our study of 17 days, taking into account that a patient can have stage I ulcers in only 72 hours, which increases the risk of complications for each day of stay. The results presented in our study highlight the care provided to the hospitalized patient in order to 
mitigate the risk. The data allow us to observe that hospitalized patients have an average stay without PU higher than that documented by the literature on the subject. Hence the importance of continuing with patient-care techniques, focused on reducing the risk of skin injuries, strengthening prevention activities in the group of low-risk patients identified in the analysis of the results (14).

\section{Conclusion}

The multivariate analysis determined that patients over 45 years old, with hemoglobin below the expected level by sex and age, are at high risk of developing PU. A large number of patients with these characteristics may be referred to hospitalization services after their stay in intensive care units, as presented in the univariate analysis.

\section{Referencias}

1. Thomas DR. Prevention and management of pressure ulcers. J Am Med Dir Assoc. 2006;7 (1):46-59. https://doi.org/10.10 16/j.jamda.2005.10.004

2. Sibbald RG, Krasner DL, Woo KY. Pressure ulcer staging revisited: superficial skin changes \& Deep Pressure Ulcer Framework (C). Adv Skin Wound Care. 2011 Dec;24(12):571-80. https://doi.org/10. 1097/01.ASW.0000408467.26999.6d

3. Brien D, Shanks A, Talsma A, Brenner P, Rammachandran S. Intraoperative Risk factor associated with postoperative pressure ulcer in critically III patients: A retrospective observational study. Crit Care Med. 2013;41(11):1-8. https://doi.org/10.10 97/CCM.0b013e318298a849

4. García F, Pancorbo P, Soldevilla J, Rodríguez M. Valoración del riesgo de desarrollar úlceras por presión en unidad de cuidado crítico: revisión sistemática con meta análisis. Gerokomos. 2013;24(2):82-9. http://dx.doi.org/10. 4321/S1134-928X2013000200007

5. Lobo A. Factores de riesgo en el desarrollo de úlceras por presión y sus implicaciones en la calidad de vida. Rev Bras Geriatr Gerontol. 2008;11(3):405-18.

6. Ministerio de Salud. Prevención úlceras por presión [Internet]. Available from: https://www.minsalud. gov.co/sites/rid/Lists/BibliotecaDigital/ RIDE/DE/CA/prevenir-úlceras-por-pr esion.pdf

7. Chacón-Mejía J, Del CarpioAlosilla AE. Indicadores clínico epidemiológicos asociados a úlceras por presión en un hospital de Lima. Rev Fac Med Hum. 2019;19(2). https://doi.org/ 10.25176/RFMH.v19.n2.2067

8. Barrera Arenas E, Pedraza Castañeda MC, Pérez Jiménez G, Hernández Jiménez P, Reyes Rodríguez A, Padilla Zárate M. Prevalencia de úlceras por presión de un hospital de tercer nivel en México DF. Gerokomos [Internet]. 2016;27(4). Available from: http://scielo.isciii.es/scielo.php?s cript $=$ sci_arttext $\&$ pid $=$ S1134-928X2 016000400009

9. Ministerio de la Protección Social de Colombia. Lineamientos para la implementación de una política de seguridad del paciente [Internet]. Bogotá; 2008. Available from: https://www.minsalud.gov.co/sit es/rid/Lists/BibliotecaDigital/RIDE/DE /CA/LINEAMIENTOS IMPLEMEN TACION POLITICA SEGURIDAD _DEL_PACIENTE.pdf

10. Iizaka S, Okuwa M, Sugama J, Sanada H. The impact of malnutrition and nutrition-related factors on the development and severity of pressure ulcers in older patients receiving home 
care. Clin Nutr. 2010;29(1):47-53. http s://doi.org/10.1016/j.clnu.2009.05.018 11. Costa A, Porto Sabino Pinho C, Almeida dos Santos A, et al. Úlcera por presión: incidencia y factores demográficos, clínicos y nutricionales asociados en pacientes de una unidad de cuidados intensivos. Nutr Hosp [Internet]. 2015;32(5):2242-52. Available from: http://www.aulamedic a.es/nh/pdf/9646.pdf

12. González-Consuegra R, Cardona Mazo D, Murcia Trujillo P, Matiz Vera G. Prevalencia de úlceras por presión en Colombia: informe. Rev Fac Med [Internet]. 2014;62(3):369-77. Available from: http://www.scielo.org.c o/pdf/rfmun/v62n3/v62n3a6.pdf

13. Torra-Bou JE, Verdú-Soriano J, Sarabia-Lavin R, Paras Bravo P, Soldevilla Agresa J, García Fernández F. Las úlceras por presión como problema de seguridad del paciente. Gerokomos [Internet]. 2016;27(4):161-7. Available from: http s://www.gerokomos.com/wp-content/u ploads/2017/01/27-4-2016-161.pdf

14. Hernández Ortiz JÁ. Prevención y cuidados en úlceras por presión: ¿Dónde estamos? Gerokomos [Internet]. 2009;20(3):132-40. Available from: htt p://scielo.isciii.es/pdf/geroko/v20n3/hel $\cos 2 . p d f$

15. Tzuc-Guardia A, Vega Morales E, Collí Novelo L. Nivel de riesgo y aparición de úlceras por presión en pacientes en estado crítico. Enferm Univ. 2015;12(4):204-11. https://doi.o $\mathrm{rg} / 10.1016 /$ j.reu.2015.10.004

16. Souza DM, Santos V. Risk factors for pressure ulcer development in institutionalized elderly. Rev Latino-Am Enferm. 2007;15(5):958-64. https://doi.org/10. 1590/S0104-11692007000500012
17. Rogenski N, Santos Vera L. Estudo sobre a incidência de úlceras por pressão em um hospital universitário. Rev Latino-Am Enferm [Internet]. 2005;13(4):474-80. Available from: https://www.scielo.br/p df/rlae/v13n4/v13n4a03.pdf

18. Diccini S, Camaduro C, Senyer Iida L. Incidência de úlceras de pressão em centro de terapia intensiva de um hospital universitário e fatores de risco relacionados. Rev Paul Enferm. 2005;23(3/4):202-7.

19. Louro M, Ferrerira M, Povoa P. Avaliação de protocolo de prevenção e tratamento de úlceras por pressão. Rev Bras Ter Intensiva. 2007;19(3):337-41. 20. Fernandes Silva N, Vasconcelos Torres G. Incidência e fatores de risco de úlceras por pressão em pacientes de unidade de terapia intensiva. Cienc Cuid Saúde. 2008;7(3):304-10.

21. Maklebust J, Sieggreen M. Pressure ulcers: prevention. Pennsylvania: Springhouse; 1996.

22. Torra i Bou J-E. Incidencia de úlceras por presión en unidades de cuidado intensivo: revisión sistemática con metaanálisis [tesis] [Internet]. Universidad de Alicante; 2016. Available from: https://gneaPU.info/incidencia-d e-úlceras-por-presion-en-unidades-decuidados-intensivos/

23. Stegensek Mejía E, Jiménez Mendoza A, Romero Gálvez L, Aparicio Aguilar A. Úlceras por presión en diversos servicios de un hospital de segundo nivel de atención. Enferm Univ. 2015;12(4):173-81. http s://doi.org/10.1016/j.reu.2015.08.004 